\title{
SPANXF1 Gene
}

National Cancer Institute

\section{Source}

National Cancer Institute. SPANXF1 Gene. NCI Thesaurus. Code C92974.

This gene may play a role in spermatid differentiation. 